\title{
A Noncanonical Release of GABA and Glutamate Modulates Neuronal Migration
}

\author{
Jean-Bernard Manent, Michaël Demarque, Isabel Jorquera, Christophe Pellegrino, Yehezkel Ben-Ari, \\ Laurent Aniksztejn, and Alfonso Represa \\ Institut de Neurobiologie de la Méditerranée, Institut National de la Santé et de la Recherche Médicale U29, Campus de Luminy BP13, 13273 Marseille, \\ France
}

Immature neurons express GABA and glutamate receptors before synapse formation, and both transmitters are released at an early developmental stage. We have now tested the hypothesis that the ongoing release of GABA and glutamate modulates neuronal migration. Using 5-bromo-2'-deoxyuridine labeling and cocultures of hippocampal slices obtained from naive and green fluorescent proteintransgenic mice, we report that migration is severely affected by $\mathrm{GABA}_{\mathrm{A}}$ or NMDA receptor antagonist treatments. These effects were also present in munc18-1 knock-out slices in which soluble $N$-ethylmaleimide-sensitive factor attachment protein receptor (SNARE)dependent vesicular secretion of transmitters has been deleted. $\mathrm{GABA}_{\mathrm{A}}$ antagonists were more efficient than NMDA antagonists to reduce cell migration, in keeping with the earlier maturation of GABAergic mechanisms. We conclude that GABA and, to a lesser degree, glutamate released in a SNARE-independent mechanism exert a paracrine action on neuronal migration.

Key words: neuron; migration; neurotransmitter; GABA; glutamate; hippocampus

\section{Introduction}

Neuronal migration is one of the critical steps of the CNS construction. Once generated in the germinal layers where they become postmitotic, immature neurons (or neuroblasts) start to migrate to reach their target fields. In the cerebral cortex, this process is well documented, with the presence of two modes of migration: (1) a radial, glial-guided mode of migration for the principal cells, identified by the early pioneering studies conducted by Rakic and colleagues (Rakic, 1971, 1972; Rakic et al., 1974), and (2) a tangential mode of migration for the interneurons, proposed by O'Rourke et al. (1992) and confirmed by Anderson et al. (1997) [for a review on both modes of migration, see Nadarajah and Parnavelas (2002)]. In the hippocampus, the process has been less investigated, but the same modes of migration likely proceed. The early birthdating studies from Bayer (1980) identified the timing of genesis of the pyramidal cells of the CA1 region between embryonic day 16 (E16) and E18 in rats [birthdates corrected according to Paxinos et al. (1991), the morning after mating being considered as E0]. Once generated, these cells start their migration toward the stratum pyramidale between E17 and E19-E20. In mice, this process occurs slightly earlier, with cells being generated between E14 and E16 (Stanfield and Cowan, 1979) and migrating afterward.

\footnotetext{
Received Sept. 7, 2004; revised March 25, 2005; accepted March 30, 2005.

This work was supported by the Ministère de l'Education Nationale de la Recherche et de la Technologie (J.-B.M. and M.D.), the Fondation de la Recherche Médicale (M.D.), and the Fondation Cino and Simone Del Duca. We are grateful to Drs. M. Okabe and T. C. Südhof for the gift of GFP and munc18-1 mutant mice. We also thank Sophie Menet for technical assistance in the early immunohistochemical analysis of the mutant mice.

Correspondence should be addressed to Dr. Alfonso Represa, Institut de Neurobiologie de la Méditerranée, Institut National de la Santé et de la Recherche Médicale U29, Campus de Luminy BP13, 13273 Marseille, France. E-mail: represa@inmed.univ-mrs.fr.

D0I:10.1523/JNEUROSCI.0553-05.2005

Copyright $\odot 2005$ Society for Neuroscience $\quad$ 0270-6474/05/254755-11\$15.00/0
}

As they migrate throughout the cerebral tissue, immature neurons are influenced by several factors that modulate their journey. Among these factors, transmitters have been shown to play an important role. Indeed, several studies that focused on various brain structures (cerebellar cortex, cerebral cortex, olfactory epithelium, basal forebrain) and neuronal subtypes (granule cells, cortical neuroblasts, tangentially migrating interneurons, luteinizing hormonereleasing hormone neuroblasts, gonadotropin-releasing hormone neuroblasts) have been performed using different protocols (dissociated cells in microchemotaxis chambers, slice preparation). These studies have led to the conclusion that transmitters, GABA and glutamate, acting on several receptor subtypes $\left(\mathrm{GABA}_{\mathrm{A}}, \mathrm{GABA}_{\mathrm{B}}\right.$, $\mathrm{GABA}_{\mathrm{C}}, \mathrm{NMDA}, \mathrm{AMPA}$ ) have a crucial modulatory effect on migrating neuroblasts, acting as motility-promoting signals (Behar et al., 1998, 1999, 2000, 2001; Hirai et al., 1999; Simonian and Herbison, 2001; Lopez-Bendito et al., 2003), acceleratory signals (Komuro and Rakic, 1993), or stop signals (Behar et al., 1998, 2000; Fueshko et al., 1998; Bless et al., 2000; Simonian and Herbison, 2001; Kihara et al., 2002). However, in contrast to these observations, there is no deficit in cortical layering and synapse formation in mice in which vesicular release has been deleted: munc18-1 mutant mice (Verhage et al., 2000) or munc13-1/2 double knock-out (KO) mice (Varoqueaux et al., 2002). The reasons for this contradiction have not been elucidated.

In a recent study, we showed that in the prenatal (E18-E20) and postnatal [postnatal day 0 ( $\mathrm{P} 0)$ to $\mathrm{P} 3$ ] hippocampus of rats and mice (Demarque et al., 2002), there is a calcium- and soluble $N$-ethylmaleimide-sensitive factor attachment protein receptor (SNARE)-independent release of GABA and glutamate. These transmitters generated large slow currents in maturing neurons, including neurons that have no functional synapses. This paracrine mode of communication, which is mediated by the activa- 
tion of $\mathrm{GABA}_{\mathrm{A}}$ and NMDA receptors, is restricted to an early developmental stage. Interestingly, this release is present in munc18-1 mutant mice (Demarque et al., 2002), suggesting that a SNARE-independent release of GABA and glutamate may contribute to the construction of brain structures.

To investigate this issue, we designed a hippocampal organotypic slice coculture assay in which fluorescent migrating pyramidal neurons can be observed easily. Using this technique, patch-clamp recordings of migrating cells indicated that these cells expressed functional $\mathrm{GABA}_{\mathrm{A}}$ and sometimes NMDA receptors. Applications of antagonists of $\mathrm{GABA}_{\mathrm{A}}$ (bicuculline) or NMDA [(5S,10R)-(+)-5methyl-10,11-dihydro-5H-dibenzo[a,d]cyclohepten-5,10-imine maleate (MK801)] receptors led to a strong impairment of neuronal migration, including in slices of munc18-1-deficient mice. Our results suggest that a paracrine, SNARE-independent release of GABA and glutamate may modulate neuronal migration.

\section{Materials and Methods}

Animals. Experiments were performed on E17-E18 rats and E16-E17 mice embryos. Wistar rats were obtained from Janvier (Janvier, France). We also used Swiss mice (Janvier), green fluorescent protein (GFP)transgenic mice (a gift from Dr. M. Okabe, Osaka University, Osaka, Japan) (Okabe et al., 1997), or munc18-1 mutant mice (a gift from Dr. T. C. Südhof, University of Texas, Dallas, TX) (Verhage et al., 2000) deficient for the brain-specific isoform of the mammalian homolog of UNC18, also called nSec1 or RbSec1 [for a review on SNAREs and Munc18, see Hata et al. (1993) and Rizo and Sudhof (2002)]. The GFP embryos were selected from the wild-type nonfluorescent littermates under UV light. The munc18-1-deficient embryos were selected from normal or heterozygous littermates because they have a smaller size and exhibit a peculiar tucked posture and edematous appearance. Furthermore, they are paralyzed and display neither spontaneous nor reflex movement after mechanical stimulation. The absence of the Munc18-1 protein in selected embryos was confirmed post hoc as described previously (Demarque et al., 2002). All experimental procedures were performed in agreement with the European Union and French legislation concerning the care and use of animals.

Pharmacological agents and antibodies. The pharmacological agents used in culture and for electrophysiology were as follows: NMDA, isoguvacine, D-2-amino-5-phosphonovaleric acid (D-APV), MK801, and bicuculline (all obtained from Tocris, Bristol, UK); and GABA and glutamate (both obtained from Sigma, St. Louis, MO).

The primary antibodies were as follows: rat anti-5-bromo-2'deoxyuridine (BrdU; 1:50; Harlan Sera-Lab, Loughbourough, UK), mouse monoclonal anti-GFP (1:2000; Molecular Probes, Eugene, OR), anti- $\beta$ III-tubulin (1:500; Sigma), anti-microtubule-associated protein 2 (MAP2; 1:500; Sigma), anti-GABA $\beta$ chain (1:200; Chemicon, Temecula, CA), rabbit polyclonal anti-GFP (1:3000; Molecular Probes), anti-NMDA receptor subunit NR1 (anti-NR1) (1:200; Chemicon), antiAMPA/KA receptor subunits $2 / 3$ (GluR2/3; $1: 200$; Chemicon), antiGFAP (1:200; Sigma), and anti-GABA (1:500; Sigma).

The secondary antibodies were as follows: donkey anti-rat conjugated with FITC (1:200), donkey anti-mouse conjugated with FITC (1:200), goat anti-mouse conjugated with Texas Red (1:200; Jackson ImmunoResearch, West Grove, PA), goat anti-rabbit conjugated with Cy3 (1:200; Molecular Probes), and goat anti-rabbit conjugated with Alexa 488 (1: 200; Molecular Probes).

Hippocampal organotypic slice culture. Pregnant animals were anesthetized with an intraperitoneal injection of chloral hydrate (7\%; Sigma) or killed by cerebral dislocation. Briefly, embryos were removed by cesarean section, and their brains were placed into Petri dishes containing cold PBS supplemented with glucose (30\%; Sigma) and penicillin-streptomycin $(50 \mathrm{mg} / \mathrm{ml}$; both from Invitrogen, San Diego, CA). The brains were cut into 350-400 $\mu \mathrm{m}$ coronal slices using a tissue chopper (McIlwain; Campden Instruments, Leicester, UK), and slices were collected into 35 $\mathrm{mm}$ Petri dishes containing culture medium (MEM, 10\% horse serum, and $25 \mu \mathrm{g} / \mathrm{ml}$ insulin). Meninges were removed gently, and hippocampal slices were prepared under a dissecting microscope, with the help of micro-tweezers and a spatula. Hippocampal slices were cultivated onto the membrane of Millicell-CM inserts (Millipore, Bedford, MA) in a 6-well plate containing $1 \mathrm{ml}$ of culture medium per well, according to the protocol developed by Stoppini et al. (1991), adapted to embryonic tissues. Three to four hippocampal slices per inserts were arranged flat onto the membrane, and the excess of culture medium was removed. The 6-well plates were kept for $1 \mathrm{~d}$ in vitro (DIV) at $37^{\circ} \mathrm{C}$ with $5 \% \mathrm{CO}_{2}$ and $95 \%$ air. During the first $2 \mathrm{~h}$ of the incubation period, BrdU $(50 \mu \mathrm{g} / \mathrm{ml}$; Sigma) was added to the culture medium. After replacing the BrdUcontaining medium with fresh medium without BrdU, pharmacological agents were added (see above).

Hippocampal organotypic slice coculture assay. Time pregnant E16-E17 GFP mice were killed by cerebral dislocation, the embryos were removed, and hippocampal slices were prepared as described above. The slices were plated onto the membrane of a Millicell-CM insert in 1 drop of medium, allowing their gentle manipulations with the help of a thin spatula. Two hippocampal slices, prepared from wild-type or GFP embryos of the same littermates (or from age-related munc18-1-deficient embryos), were arranged flat, in very tight apposition at the level of the neuroepithelium of the CA1 region (see Fig. $1 \mathrm{~A}$ for a schematic view of the coculture assay). The medium in excess was then removed, and the 6-well plates were kept for $1 \mathrm{DIV}$ at $37^{\circ} \mathrm{C}$ with $5 \% \mathrm{CO}_{2}$ and $95 \%$ air, in the presence or in the absence of pharmacological agents.

The permissiveness of the host environment for migration was assessed using various experimental conditions [i.e., homotypic (mice vs mice, from the same littermates when possible) or heterotypic (mouse vs rat), homochronic (age-related slices) or heterochronic slices], revealing no differences in the amount and distribution of migrated cells. The majority of coculture assays presented here were performed using homotypic, homochronic slices. Concerning the "hippocampal" specificity of the migration substrate, fluorescent age-related cortical slices were cocultivated with wild-type hippocampal slices. In this condition, cortical cells migrated but failed to reach the pyramidal layer, suggesting that a hippocampal environment is specific for a normal hippocampal cell migration.

Electrophysiological recordings of migrating cells. Cocultured organotypic slices were placed in a recording chamber where they were fully submerged and superfused at a flow rate of $2-3 \mathrm{ml} / \mathrm{min}$ with an oxygenated artificial CSF of the following composition (in mM): $126 \mathrm{NaCl}, 3.5$ $\mathrm{KCl}, 2 \mathrm{CaCl}_{2}, 1.3 \mathrm{MgCl}_{2}, 25 \mathrm{NaHCO}_{3} 1.2 \mathrm{NaHPO}_{4}$, and 10 glucose $(95 \%$ $\mathrm{O}_{2}$ and $5 \% \mathrm{CO}_{2}, \mathrm{pH} 7.4,32-34^{\circ} \mathrm{C}$ ). GFP migrating neuroblasts were visualized with a fluorescent upright microscope (Axioscope; Zeiss, Oberkochen, Germany) equipped with an appropriate filter and recorded using the patch-clamp technique in the whole-cell configuration. Microelectrodes had a resistance of 8-10 $\mathrm{M} \Omega$ and were filled with a solution containing either (in $\mathrm{mm}$ ) $120 \mathrm{KCl}, 10 \mathrm{KGlu}, 0.1 \mathrm{CaCl}_{2}, 1.1$ EGTA, 10 HEPES, $4 \mathrm{Mg}^{2+} \mathrm{ATP}$, and $0.3 \mathrm{Na}^{+} \mathrm{GTP}$ (KCl-filled pipette electrode) or $120 \mathrm{CsGlu}, 10 \mathrm{CsCl}, 0.1 \mathrm{CaCl}_{2}, 1.1$ EGTA, 10 HEPES, 4 $\mathrm{Mg}^{2+}$ ATP, and $0.3 \mathrm{Na}^{+}$GTP, pH 7.25, 270-280 mOsm (CsGlu-filled pipette electrode). In some experiments, rhodamine was added in the pipette electrode. Whole-cell measurements in voltage-clamp or current-clamp mode were filtered at $3 \mathrm{kHz}$ using an EPC-9 amplifier (HEKA Elektronik, Lambrecht/Pfalz, Germany). All data were digitized $(1-2 \mathrm{kHz})$ with a digidata (Molecular Devices, Union City, CA) interface card to a personal computer.

BrdU incorporation into dividing cells. After undergoing their final division at the level of the neuroepithelium, postmitotic cells, presumptive neuroblasts, start to migrate to reach their target layers. BrdU is incorporated into those dividing cells during the $S$ phase of their cell cycle and remains integrated into their DNA during their life span. Thus, BrdU allows the monitoring of age-related postmitotic migrating cells, from their birthplace to their target layer. The BrdU signal is, however, diluted if the cells undergo additional rounds of division, being distributed to the daughter cells.

BrdU was either administrated by an intraperitoneal injection of the pregnant animals with $50 \mathrm{mg}$ of BrdU per kilogram of body weight $2 \mathrm{~h}$ before the preparation of the slices or applied in culture as described above. When injections were performed in pregnant animals for birth- 
dating analysis (from E12 to E19), littermates were allowed to birth and to survive until P7-P8 and P14-P15. They were then perfused intracardially with the fixative solution (4\% paraformaldehyde and $0.5 \%$ glutaraldehyde in PBS), and the brains were cut coronally with a vibratome (Leica, Nussloch, Germany).

Immunohistochemistry on slices and sections. After $1 \mathrm{DIV}$, cultures were fixed overnight at $4^{\circ} \mathrm{C}$ in $4 \%$ paraformaldehyde and rinsed the next day. Fixed sections were rinsed three times in PBS. All processing was the same for both cases (cultures and sections) starting from this point. Slices were permeabilized for $10 \mathrm{~min}$ at room temperature in PBS-Triton X-100 (0.1\%)-goat serum (5\%). For BrdU staining, the permeabilization step was followed with a $20 \mathrm{~min}$ incubation in PBS- $\mathrm{HCl} 2 \mathrm{~N}$ at $45^{\circ} \mathrm{C}$. After permeabilization, slices were washed three times in PBS and incubated overnight at room temperature with primary antibodies diluted in PBS-Triton X-100 (0.1\%)-goat serum (5\%). The slices were rinsed three times in PBS and incubated for $2 \mathrm{~h}$ at room temperature in appropriated secondary antibodies, used separately for double immunolabeling. After three final washes in PBS, slices were mounted on glass slides and coverslipped in Gel Mount (Biomedia, Foster City, CA).

Slices were examined on an Olympus Fluoview confocal microscope using $20 \times$ and $40 \times$ objectives, and pictures were digitized in tiff format using the built-in software Fluoview.

Imaging of living slices was performed on a Nikon Diaphot inverted microscope equipped with a Nikon DXM1200F digital camera, and pictures were digitized in tiff format using the built-in software Nikon ACT-1.

Quantitative analysis of migrated cells and birthdating studies. Once digitized, pictures were analyzed with Photoshop 7.0 (Adobe Systems, Mountain View, CA) using custom-made methods and/or the analysis software Image 1.33d (Wayne Rasband, National Institutes of Health, Bethesda, MD). Slices containing BrdU-labeled cells or fluorescent migrating neuroblasts were divided into two areas: (1) the "migration area," from the neuroepithelium to the stratum oriens, virtually containing migrating cells; and (2) the "destination area," the stratum pyramidale, virtually containing cells that have reached their final destination. The number of cells was quantified in each area and expressed as a percentage of the total number of cells $( \pm S E M)$. Data were then expressed as migration indices. The migration indices were calculated as the ratio between the percentage of cells that reached the stratum pyramidale after 1 DIV and the percentage of cells that were still in the migration area, with the average of the control values being set to 10 . For the monitoring of age-related postmitotic migrating cells, only the round-shaped, heavystained, BrdU + cells were included in the analysis, virtually corresponding to cells that underwent their final mitosis during the pulse of BrdU.

For fluorescent neuroblasts located in the migration area, the orientation of the leading processes was measured with respect to the "correct" direction of radial migration (i.e., perpendicular to the interface between the fluorescent and the nonfluorescent slice, linking the neuroepithelium to the stratum pyramidale and corresponding to an angular deviation of $\left.0^{\circ}\right)$. In this analysis, the leading process is considered as a vector, originating from the center of the soma and pointing to the tip of the growth cone. The angular deviation between the vector and the correct direction of migration is then measured, and migrated cells are distributed into three groups: (1) cells with leading process orientations that deviate from $0^{\circ}$ to $70^{\circ}$ of the correct direction of migration (these cells are referred to as "well oriented" migrating neuroblasts); (2) cells with leading process orientations that deviate from $70^{\circ}$ to $110^{\circ}$; and (3) cells with leading process orientations that deviate from $110^{\circ}$ to $180^{\circ}$.

All quantitative analyses were performed using stereological methods. The normality of the data distribution was checked using SigmaStat (Systat Software, Point Richmond, CA). Statistical analyses were performed with Origin 7.0 (Origin Lab, Northampton, MA), and statistical significance was assessed using the $t$ test and ANOVA.

\section{Results}

The hippocampal organotypic slice coculture assay allows the visualization of fluorescent migrating neuroblasts

Our first task was to design a preparation in which neurons can be visualized when migrating and patch-clamp recorded to deter- mine the presence of functional receptors. For this purpose, we designed a hippocampal organotypic slice coculture assay in which E17-E18 hippocampal slices from GFP and wild-type mice were cocultured in tight apposition at the level of the neuroepithelium of the CA1 region (see Materials and Methods) (Fig. $1 A, B)$. The embryonic age was chosen after reevaluation of the period of genesis of CA1 pyramidal cells in mice using BrdU (which goes from E14 to E18) (see supplemental data and Figs. S1 $A$ and S1 $B$, available at www.jneurosci.org as supplemental material). Under this condition, many GFP cells generated in the germinal layer of the CA1 region (i.e., the neuroepithelium) exit the GFP donor slice to migrate onto the nonfluorescent host slice. After 1 DIV, many fluorescent cells had migrated onto the wildtype slice, and some of them had reached the stratum pyramidale (Fig. 1C). These cells already expressed neuronal markers such as MAP2 $(24.18 \pm 3.12 \%, 149$ of 649 cells) (Fig. $1 D$ ) or $\beta$ III-tubulin (32.54 $\pm 0.67 \%, 219$ of 678 cells) (Fig. $1 D$ ) but not glial markers (GFAP; data not shown). Thus, the majority of fluorescent migrating cells were migrating neuroblasts expressing neuronal, but not glial, markers. These migrating neuroblasts were presumptive young CA1 pyramidal cells regarding their age of genesis (see supplemental data and Figs. S1 $A$ and $\mathrm{S} 1 B$, available at www. jneurosci.org as supplemental material) and the absence of GABA immunoreactivity in virtually all GFP-positive cells (Fig. $1 E)$. In addition, most of these neuroblasts (72.99\%, 916 cells, 24 experiments) migrated with a minimal deviation to their correct direction of migration according to the orientation of the leading processes (mean deviation, $30.21 \pm 0.59^{\circ}$; see Materials and Methods). These migrating cells were referred to as well oriented migrating neuroblasts.

\section{Migrating neuroblasts express functional $\mathrm{GABA}_{\mathrm{A}}$ and NMDA receptors}

Parallel immunocytochemical experiments (Fig. 2) showed that migrating neuroblasts were immunoreactive to NMDA (Fig. $2 A-C, N R 1$ ) and $\mathrm{GABA}_{\mathrm{A}}$ (Fig. $2 D-F$ ) receptors, suggesting that they could respond to ambient transmitters released from adjacent structures (see supplemental data and Fig. S1C, available at www.jneurosci.org as supplemental material). To determine the functionality of these receptors, we performed electrophysiological experiments in which migrating neuroblasts in the coculture assay were patch-clamp recorded after 1 DIV (Fig. 2G). Only the well oriented migrating neuroblasts were included in the electrophysiological analysis. These migrating cells had a mean capacitance of $6.0 \pm 0.3 \mathrm{pF}(n=25)$, a resting membrane potential of $-47 \pm 8 \mathrm{mV}$ (measured with a KCl-filled electrode; $n=6$ ), and an input resistance of $3.3 \pm 1.8 \mathrm{G} \Omega(n=6)$. In some neuroblasts (4 of 10), a depolarizing pulse evoked a small action potential (or spikelet) of 10-20 mV amplitude (Fig. $2 \mathrm{H}$ ), generated at a membrane threshold approximately $-30 \mathrm{mV}$, suggesting that some of these cells are potentially excitable. We then determined whether these cells expressed functional GABA and glutamate receptors. Bath application of GABA (100 $\mu \mathrm{M} ; n=2)$ or isoguvacine (10 $\mu \mathrm{M} ; n=7)$, specific agonists of $\mathrm{GABA}_{\mathrm{A}}$ receptors, generated currents $[37 \pm 2 \mathrm{pA}(n=2)$ or $49 \pm 12 \mathrm{pA}(n=6$ of 7 cells $)$, respectively] (Fig. 2I). These currents were blocked by bicuculline $(20 \mu \mathrm{M})$, a specific antagonist of $\mathrm{GABA}_{\mathrm{A}}$ receptors (Fig. $2 I$ ). Bath application of glutamate $(100 \mu \mathrm{M} ; n=4)$ also generated a current of $20 \pm 17 \mathrm{pA}$. In addition, NMDA $(30-100 \mu \mathrm{M})$ generated currents of $54 \pm 14 \mathrm{pA}$ in 6 of 12 migrating cells (Fig. $2 \mathrm{I}$ ). These currents were not observed when $50 \mu \mathrm{M}$ D-APV (specific competitive antagonist of NMDA receptors) was coapplied with NMDA. Bath application of 3-30 $\mu \mathrm{M}$ AMPA (agonist of 

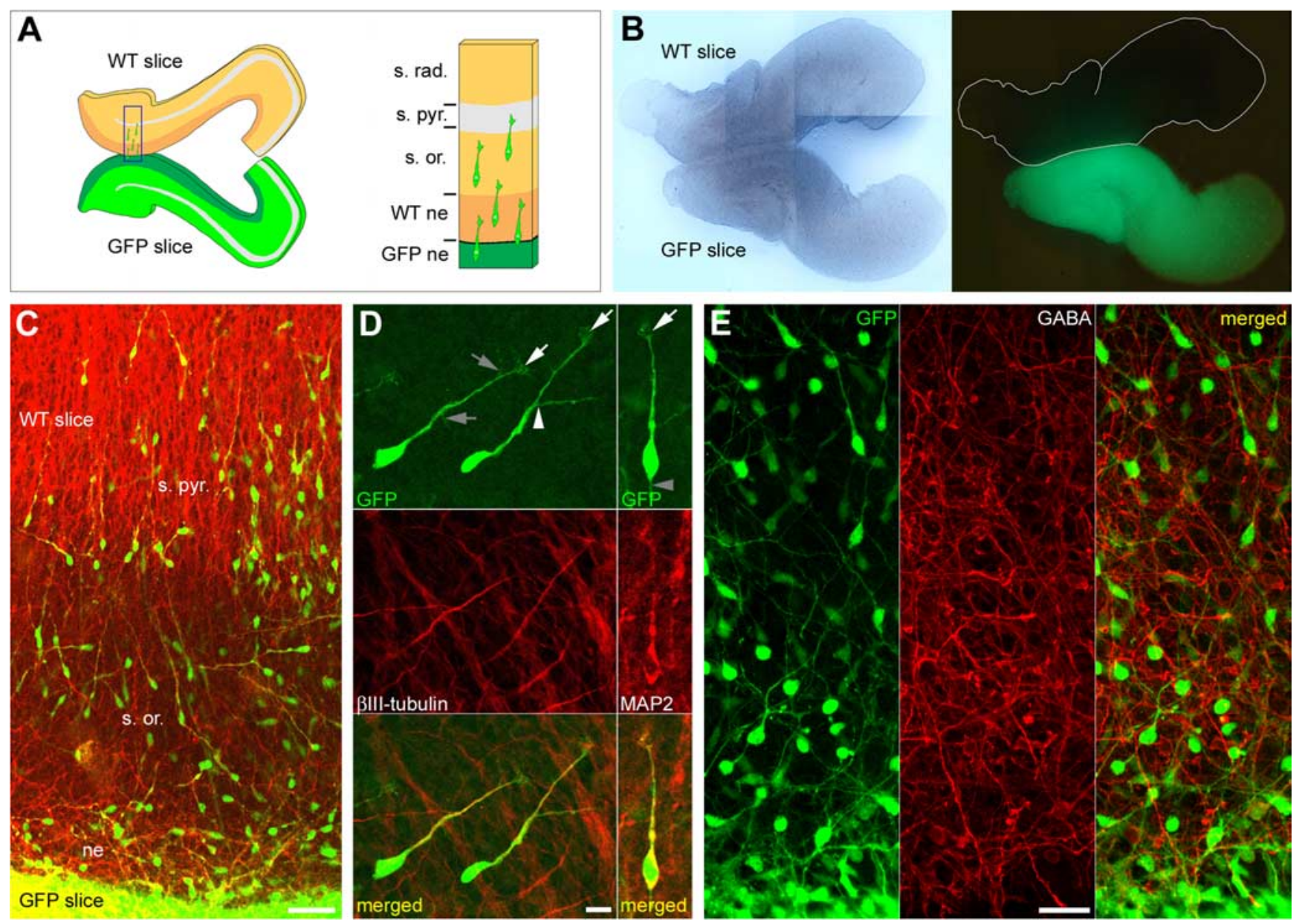

Figure 1. Migrating neuroblasts in the hippocampal organotypic slice coculture assay. $A$, Left, Diagram depicting the two hippocampal organotypic slices as they are arranged in the coculture assay. The two slices, the fluorescent donor slice and the nonfluorescent host slice, are plated in very tight apposition one relative to another, at the level of the neuroepithelium of the CA1 region. Right, Higher magnification of the square shown in the left panel. Fluorescent (GFP) migrating neuroblasts, originated in the neuroepithelium of the GFP slice (GFP ne), are migrating onto the nonfluorescent slice to reach the stratum pyramidale (s. pyr.), crossing the migration area [i.e., the neuroepithelium of the nonfluorescent slice (WT ne) and the future stratum oriens (s. or.)]. s. rad., stratum radiatum. $\boldsymbol{B}$, Images of living cocultivated hippocampal slices, as they appear $1 \mathrm{~h}$ after plating onto the membrane of a Millicell-CM insert, in light transmission (left) and under UV light (right). The borders of the nonfluorescent slice are shown in white. C, Immunostaining of E17 slices cocultured for 1 DIV showing migrating neuroblasts double-labeled with antibodies against GFP (green) and $\beta I I I-t u b u l i n$ (red). Most neuroblasts originated in the fluorescent slice (GFP slice) are migrating radially onto the nonfluorescent slice (WT slice) toward the s. pyr., crossing the future s. or. ne, Neuroepithelium. D, Immunostaining of E17 slices cocultured for 1 DIV, showing migrating neuroblasts at larger magnification, double-labeled with antibodies against GFP (green; top) and $\beta$ III-tubulin (red; left middle) or MAP2 (red; right middle). Green and red channels are merged in bottom panels. Migrating neuroblasts are either monopolar with a single leading process or bipolar with a branched leading process (white arrowhead in the left top panel). They often display a short trailing process (gray arrowhead in the right top panel). Lamellipodia are distinguishable at the tip of the leading process (white arrows in the top panels), and few filopodia are often present along the process (gray arrows in the left top panel). $\boldsymbol{E}$, Immunostaining of E17 slices cocultured for 1 DIV, showing GFP-positive migrating neuroblasts (green; left) and GABA-positive fibers (red; middle). Virtually all GFP-positive migrating neuroblasts are immunonegative to GABA (merged green and red channels on the right panel). Scale bars: $\boldsymbol{C}, 50 \mu \mathrm{m} ; \boldsymbol{D}, 10 \mu \mathrm{m} ; \boldsymbol{E}, 25 \mu \mathrm{m}$.

AMPA/KA receptors) failed to evoke any currents in all migrating neuroblasts recorded (mean capacitance, $5.5 \pm 0.6 \mathrm{pF} ; n=4$ ), suggesting that those cells do not express functional AMPA/KA receptors. When agonists for NMDA and $\mathrm{GABA}_{\mathrm{A}}$ receptors were sequentially applied, GABA- but not NMDA-evoked currents were observed in 4 of 10 cells, GABA- and NMDA-evoked currents were observed in 5 of 10 cells, and only NMDA-evoked currents were observed in only 1 of 10 cells. These data suggest that the majority of migrating neuroblasts expressed $\mathrm{GABA}_{\mathrm{A}}$ receptors ( 9 of 10 cells) and only a subset coexpressed NMDA receptors ( 5 of 10 cells). Therefore, functional $\mathrm{GABA}_{\mathrm{A}}$ receptors predominate in that they are present in almost all migrating neuroblasts.

As illustrated in our previous report, ambient GABA can activate maturing pyramidal cells in a tonic manner (Demarque et al., 2002). We therefore investigated whether migrating neuro- blasts were also tonically activated by ambient GABA. When specific antagonists of the $\mathrm{GABA}_{\mathrm{A}}$ receptors $(20 \mu \mathrm{m}$ bicuculline plus $100 \mu \mathrm{M}$ picrotoxin) were coapplied, a current associated with a decrease in the basal noise was unmasked in some migrating cells ( 2 of 10 cells) (Fig. $2 J$ ). The addition of glutamate receptor antagonists failed to generate any current. This suggests that ambient GABA can activate migrating neuroblasts in a tonic manner. However, only a subset of them would be concerned or alternatively would be tonically activated only during a transient period of their journey to the pyramidal cell layer.

\section{$\mathrm{GABA}_{\mathrm{A}}$ and NMDA receptor antagonists perturb neuronal migration in the coculture assay}

To determine the role of GABA and glutamate on migration, we tested the effects of the treatments with antagonists of the receptors functionally expressed by migrating neuroblasts (i.e., antag- 

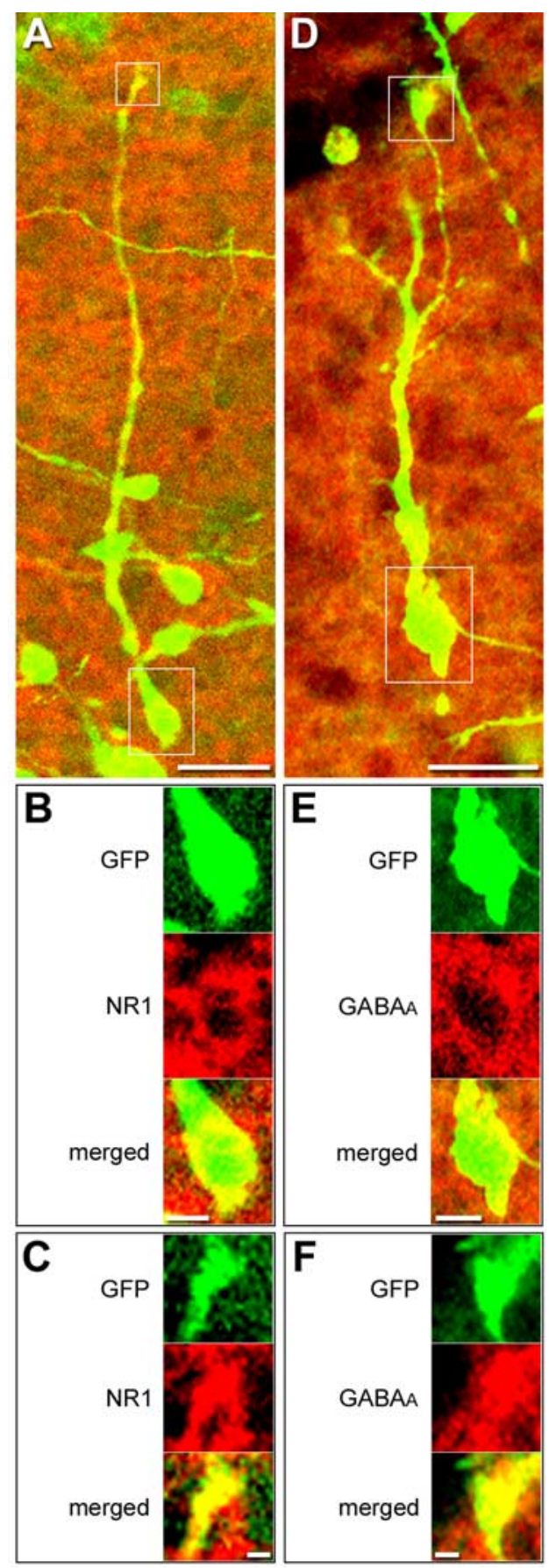
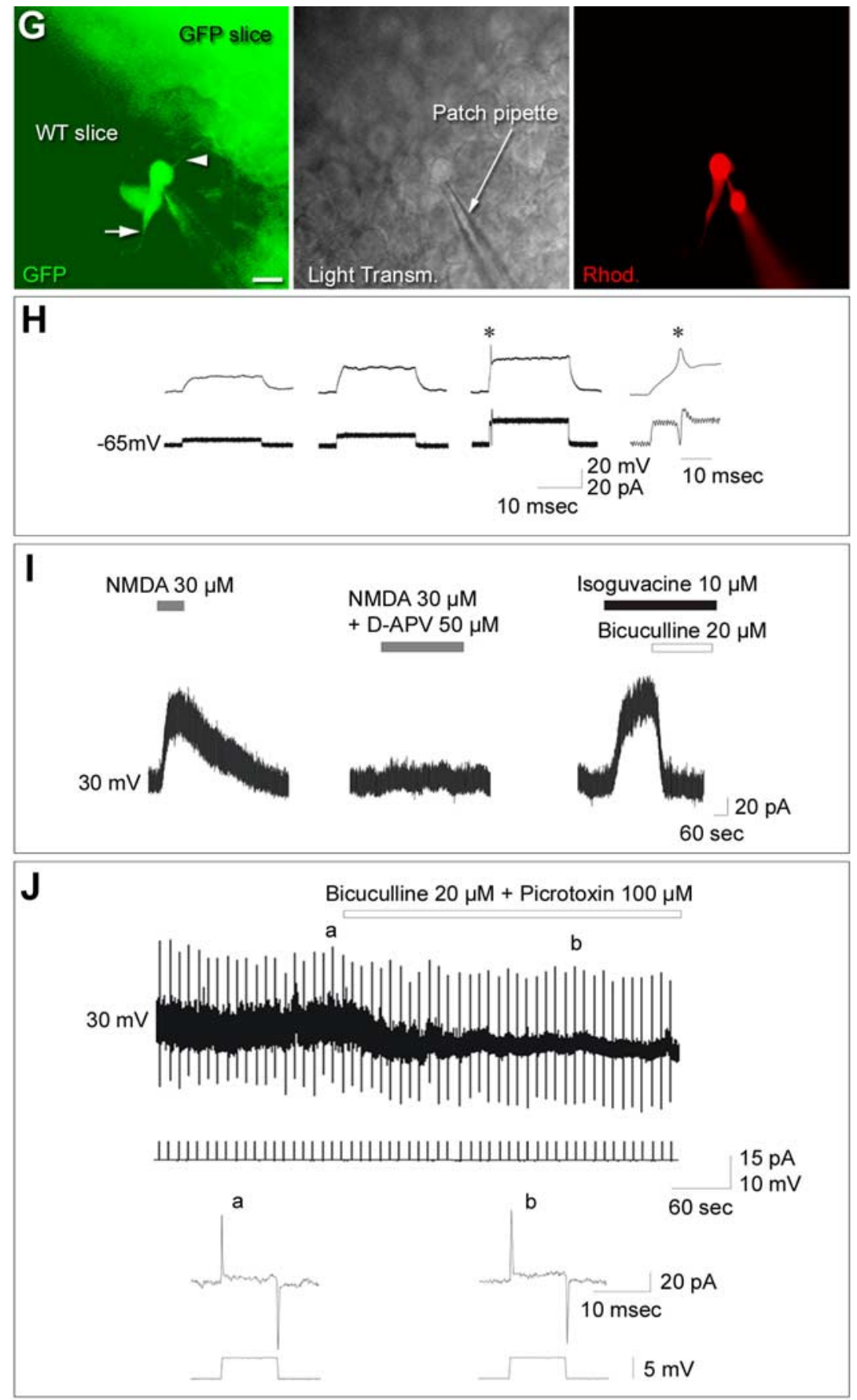

Figure 2. Receptor expression and electrophysiological properties of migrating neuroblasts. $A-C$, Immunostaining of an E17 slice cocultured for 1 DIV showing a migrating neuroblast doublelabeled with antibodies against GFP (green; $\boldsymbol{A}$ and top panels in $\boldsymbol{B}$ and $\boldsymbol{C}$ ) and NR1 subunit of the NMDA receptor (red; $\boldsymbol{A}$ and middle panels in $\boldsymbol{B}$ and $\boldsymbol{C}$ ). Squares surrounding the soma and the tip of the leading process are shown enlarged in $\boldsymbol{B}$ and $\boldsymbol{C}$. Green and red channels are merged in the bottom panels in $\boldsymbol{B}$ and $\boldsymbol{C}$. D-F, Immunostaining of E17 slices cocultured for 1 DIV showing a migrating neuroblast double-labeled with antibodies against GFP (green; $\boldsymbol{D}$ and top panels in $\boldsymbol{E}$ and $\boldsymbol{F}$ ) and $G_{A B A_{A}}$ receptor (red; $\boldsymbol{D}$ and middle panels in $\boldsymbol{E}$ and $\boldsymbol{F}$ ). Squares surrounding the soma and the tip of the leading process are shown enlarged in $\boldsymbol{E}$ and $\boldsymbol{F}$. Green and red channels are merged in the bottom panels in $\boldsymbol{E}$ and $\boldsymbol{F}$. $\boldsymbol{G}$, Photomicrograph of a GFP-positive migrating neuroblast recorded with a pipette filled with rhodamine. Left, GFP-positive neuroblast originated into the fluorescent slice (GFP slice) migrating onto the nonfluorescent hippocampal slice (WT slice). The arrow points the leading process, and the arrowhead points to the trailing process. Middle, The same neuroblast shown in light transmission (Light Transm.), impaled with the patch pipette. Right, The same neuroblast filled with rhodamine (Rhod.). $\boldsymbol{H}$, Spikelet evoked by depolarizing pulses applied to a migrating neuroblast recorded with a KCl-filled pipette solution. The capacitance of the cell was 10 pF. The spikelet (indicated with an asterisk and shown at lower time scale on the right) is evoked at a membrane potential of $-25 \mathrm{mV}$. $I$, Currents mediated by bath application of NMDA and isoguvacine and recorded at $30 \mathrm{mV}$ in the same cell $\left(C_{m}, 6 \mathrm{pF}\right)$ with a $(s G l u$-filled pipette solution. Both receptor-mediated currents are blocked by their respective antagonists.J, Migrating neuroblast $\left(C_{m}, 3 \mathrm{pF}\right)$ recorded at $30 \mathrm{mV}$ with a $\mathrm{Cs}$ Glu-filled pipette solution. Bath application of $\mathrm{GABA}_{\mathrm{A}}$ receptor antagonists generates an inward current associated with a decrease of the basal noise. Depolarizing pulses $(5 \mathrm{mV}, 10 \mathrm{~ms}$, applied every $10 \mathrm{~s})$ show that these effects are not associated with changes in the serial resistance. The bottom traces show representative responses to the current pulse before (a) and at the plateau (b) of the tonic current. Scale bars: $A, D, 20 \mu \mathrm{m} ; \boldsymbol{B}, \boldsymbol{E}, 5 \mu \mathrm{m} ; \boldsymbol{C}, \boldsymbol{F}, 2 \mu \mathrm{m} ; \mathbf{G}, 10 \mu \mathrm{m}$. 
onists of $\mathrm{GABA}_{\mathrm{A}}$ and NMDA receptors). Cells in the hippocampal organotypic slices coculture assay were allowed to migrate in a culture medium supplemented with pharmacological agents. After 1 DIV, migrated cells were quantified, and results were expressed as migration indices (see Materials and Methods). After 1 DIV in the presence of $10 \mu \mathrm{M}$ MK801, an antagonist of the NMDA receptors, the migration index was reduced by 2.8 units (from $10.05 \pm 0.87$ in the control condition to $7.19 \pm 1.25$ after MK801; $p=0.090$; six experiments; 298 cells). After 1 DIV in the presence of $50 \mu \mathrm{M}$ bicuculline, an antagonist of the $\mathrm{GABA}_{\mathrm{A}}$ receptors, the migration index was reduced by 3.1 units (from $10.05 \pm 0.87$ in the control condition to $6.92 \pm 0.68$ after bicuculline; $p=0.018$; six experiments; 419 cells).

We also investigated the morphological characteristics of migrating neuroblasts located in the migration area (i.e., from the neuroepithelium to the stratum oriens). We first examined the orientation of the leading processes, considering this orientation as an index of the direction of migration (see Materials and Methods) (Fig. $3 A$ ). There were no significant differences between groups (control slices, MK801treated slices, and bicuculline-treated slices), with the majority of cells (on average, $73.02 \pm 4.32 \%$ for the three conditions) (Fig. $3 B$ ) migrating with a minimal deviation from the correct direction of migration (the majority of cells for the three conditions migrated with a mean deviation of $30.65 \pm 0.93^{\circ}$ ). We then measured the length of the leading processes after treatment with MK801 and bicuculline. We noticed a significant reduction in the length of the leading processes, after 1 DIV in the presence of MK801 (49.64 \pm 1.20 $\mu \mathrm{m} ; p=0.004 ; 8$ experiments; 418 cells) (Fig. $3 C, D)$ and after 1 DIV in the presence of bicuculline $(46.09 \pm 1.08 \mu \mathrm{m} ; p=3.50 \mathrm{E}-$ 08; 8 experiments; 404 cells) (Fig. $3 C, D$ ), compared with the control condition (53.46 $\pm 0.68 \mu \mathrm{m} ; 24$ experiments; 1182 cells) (Fig. 3C,D).

Thus, antagonizing the effects of GABA and glutamate impaired neuronal migration in the coculture assay, affecting the length of the leading processes but without affecting the orientation of the migration, suggesting a motility defect rather than a guidance deficit. However, the amplitude of the effects of treatments with antagonists was slightly blurred by the fact that migrating neuroblasts in the coculture assay are likely to represent a heterogeneous population of cells, being generated at different time periods, resulting in successive waves of migration. To be able to investigate the effect of antagonist application on a single age-related population of migrating cells, we shifted to label premigratory cells by using BrdU incorporation into dividing cells on isolated hippocampal organotypic slices.

$\mathrm{GABA}_{\mathrm{A}}$ and NMDA receptor antagonists perturb the migration of BrdU-labeled cells in hippocampal organotypic slices culture

The effects of the application of receptor antagonists were evaluated on a population of age-related premigratory cells labeled
B

Angular distribution of the leading processes

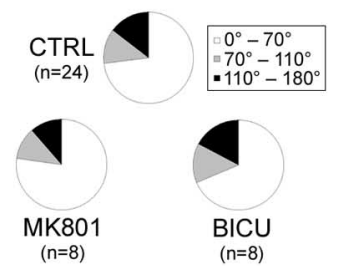

C
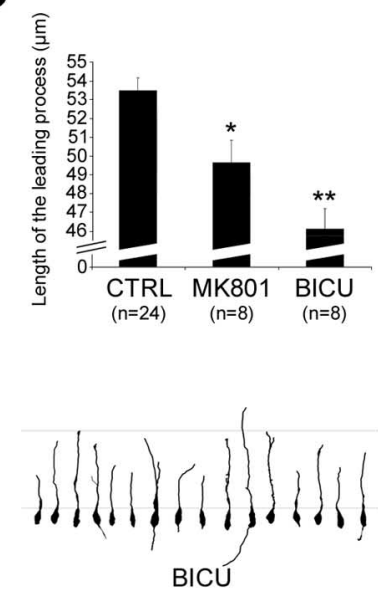

MK801

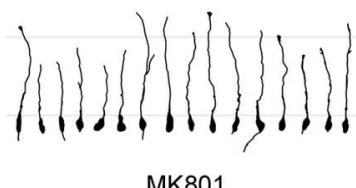
Figure 3. Treatment with receptor antagonists affects the length of the leading processes of migrating neuroblasts without
affecting their orientation. $\boldsymbol{A}$, The orientation of the leading processes is evaluated with respect to the correct direction of migration (corresponding to an angular deviation of $0^{\circ}$ ). Migrating neuroblasts located in the migration area [i.e., the neuroeppresence of MK801, or in the presence of bicuculline. The number of experiments is given in parentheses. $C$, Length of the leading bicuculline. Sixteen reconstructed migrating neuroblasts are shown per condition. The distance between the gray horizontal bars is $50 \mu \mathrm{m}$. CTRL, Control, absence of any treatment; BICU, bicuculline.

with BrdU. Cells in isolated hippocampal organotypic slices were pulse-labeled with BrdU for $2 \mathrm{~h}$ and allowed to migrate in a culture medium supplemented with pharmacological agents. After 1 DIV, BrdU-labeled migrating cells were quantified, and the results are shown in Fig. 4, as explained previously. Under these conditions, we were able to investigate the migration of a virtually unique and homogenous wave of BrdU+ migrating cells, those generated during the pulse of BrdU. The migration of this homogenous population of cells was then only influenced by factors (and supplemental pharmacological agents) that were present in their own environment. After 1 DIV in the presence of $10 \mu \mathrm{M}$ MK801, the migration index was reduced by 8 units (from $10.00 \pm 2.09$ in the control condition to $1.96 \pm 0.26$ after MK801; $p=0.0003 ; 12$ experiments; 1519 cells) (Fig. 4 B). After 1 DIV in the presence of $50 \mu \mathrm{M}$ bicuculline, the migration index was reduced by 9 units (from $10.00 \pm 2.09$ in the control condition to $1.15 \pm 0.26$ after bicuculline; $p=0.0002 ; 11$ experiments; 1129 cells) (Fig. 4 B). Importantly, the pharmacological treatments had no effects on the total number of BrdU-labeled cells (data not shown), suggesting that the proliferation rate and cell survival were not affected by the treatments. Thus, antagonizing the effects of GABA and glutamate acting through $\mathrm{GABA}_{\mathrm{A}}$ and NMDA receptors, respectively, reduced the number of neuroblasts that migrated to their correct target layer. We next investigated whether a nonconventional SNARE-independent release of transmitters mediates these effects (Demarque et al., 2002).

\section{Hippocampal cytoarchitecture and receptor expression are not altered in munc18-1 mice}

In agreement with a previous study (Verhage et al., 2000), the general architecture of the cortex was not altered in munc18-1 KO mice. Thus, in E17 hippocampal slices from munc18-1 mu- 


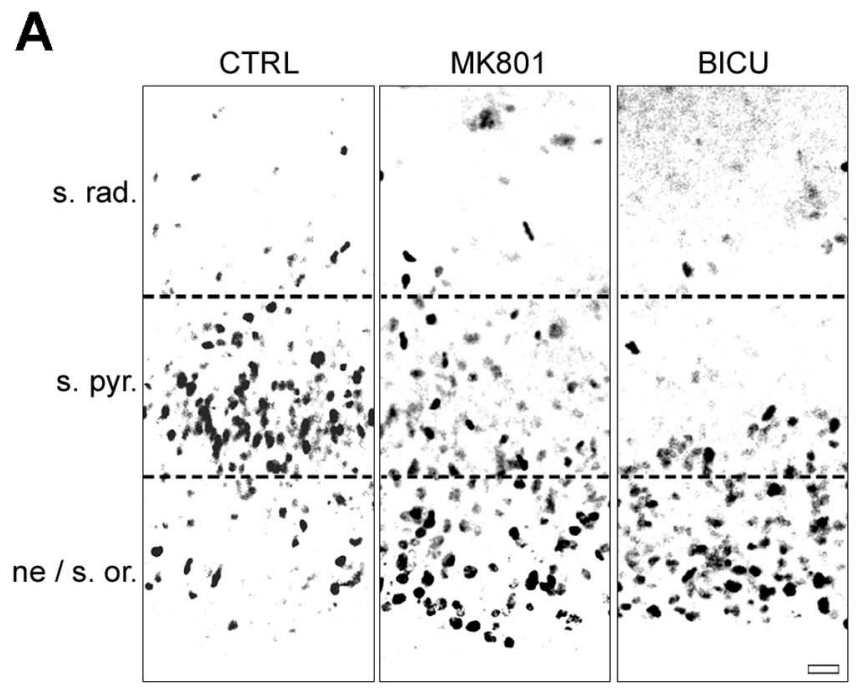

B

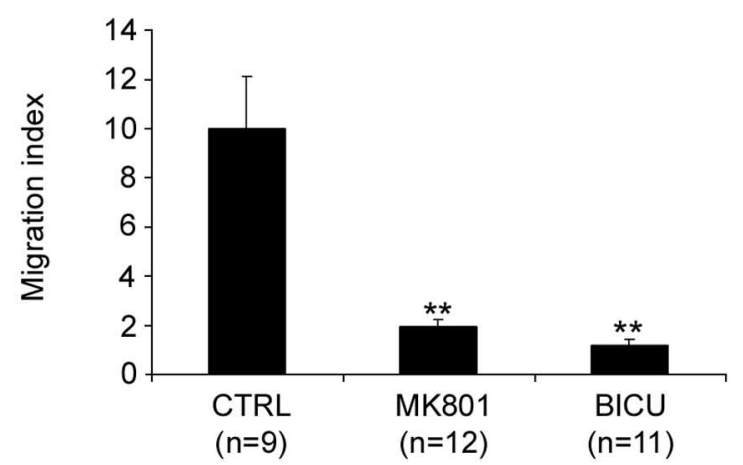

Figure 4. $G A B A_{A}$ and NMDA receptor antagonists prevent the BrdU-labeled cells from migrating to the stratum pyramidale in hippocampal organotypic slice culture. $A$, Immunostaining for BrdU on hippocampal organotypic slices cultured for 1 DIV without any treatment (control condition; left), in the presence of $10 \mu \mathrm{M}$ MK801 (middle), and in the presence of $50 \mu \mathrm{M}$ bicuculline (right). In the absence of any treatment, the majority of BrdU + cells after 1 DIV has migrated to settle into the stratum pyramidale (s. pyr.). After 1 DIV, in the presence of MK801 or bicuculline, BrdU + cells that have failed to migrate are mainly distributed into the migration area [i.e., neuroepithelium (ne)/stratum oriens (s. or.)]. Scale bar, $20 \mu \mathrm{m}$. $\boldsymbol{B}$, Histogram showing the migration indices obtained after treatment for 1 DIV with $10 \mu \mathrm{M}$ MK801 or $50 \mu \mathrm{M}$ bicuculline compared with the untreated control condition. The migration indices are expressed ( \pm SEM) as the ratio between the percentage of cells that reached the stratum pyramidale after 1 DIV and the percentage of cells that were still in the migration area (i.e., from the neuroepithelium to the stratum oriens), with the average of the control values being set to $10 .{ }^{* *} p<$ 0.001. The number of experiments is given in parentheses. CTRL, Control; BICU, bicuculline.

tant mice, the CA1 pyramidal layer was not different from controls (Fig. 5). Furthermore, few pyramidal cells already displayed a MAP2-positive short apical dendrite (Fig. 5C,D, insets), suggesting that the apical dendrite outgrowth would not require the vesicular secretion of transmitters. Moreover, there was no obvious difference in receptor expression in the mutant compared with the wild type. The NR1 subunit of the NMDA receptors was present throughout the strata oriens and pyramidale (Fig. 5A,B), mainly expressed around the soma (Fig. $5 A, B$, insets). The GluR2/3 subunits of the AMPA receptors and the $\mathrm{GABA}_{\mathrm{A}}$ receptors (Fig. $5 C-F$ ) were also present on cells located in the stratum oriens and in the stratum pyramidale. These receptors were mainly somatic and, when present, were also detected on apical dendrites (Fig. 5, insets). Because receptor expression and organization of the pyramidal layer were not impaired in the absence of vesicular secretion of transmitters, we then investigated whether neuronal migration is affected.

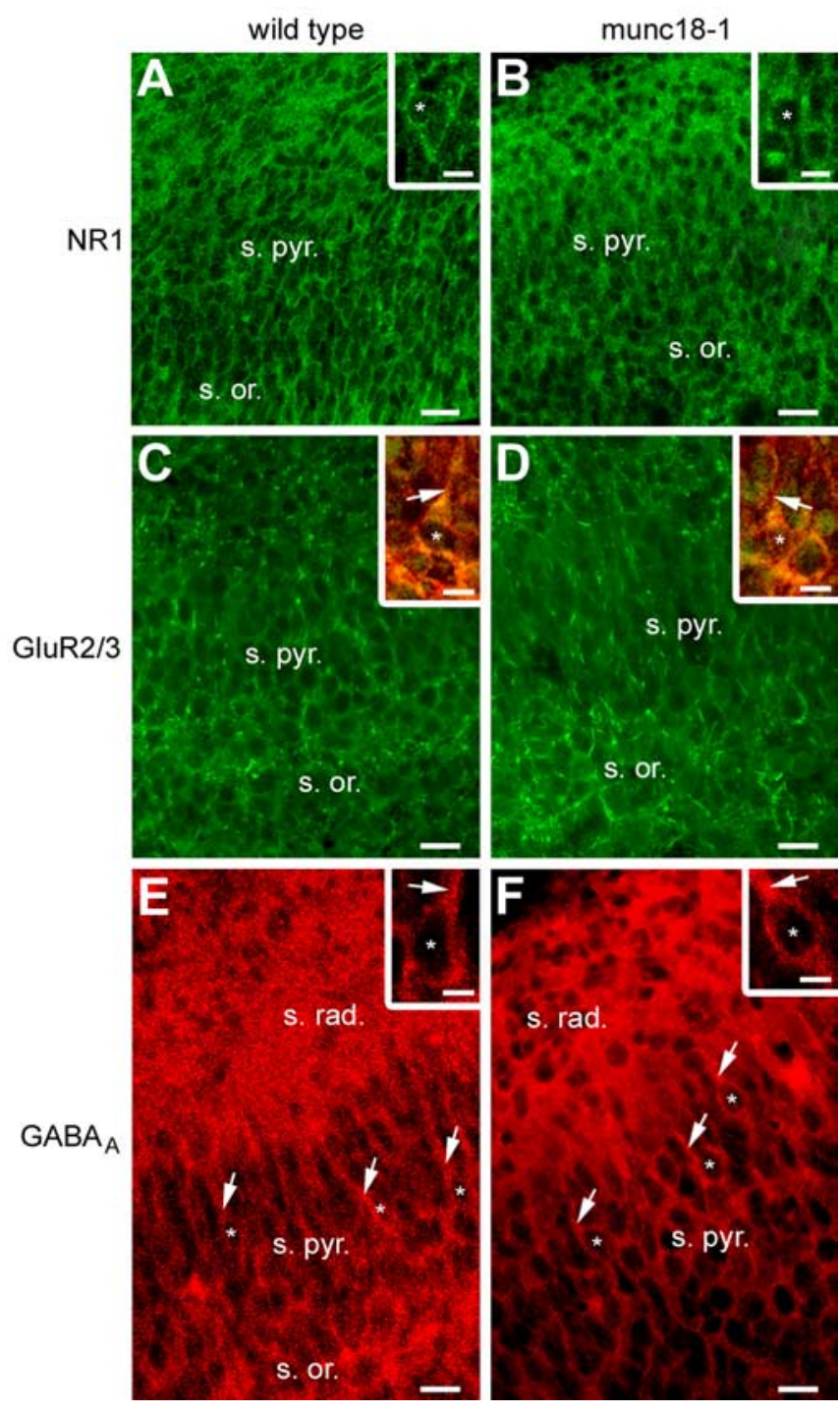

Figure 5. Receptor expression and hippocampal cytoarchitecture in munc18-1 mutants mice versus wild-type mice at late prenatal stages. $A, B$, Immunostaining for the NR1 subunit of the NMDA receptor on E17 hippocampal sections, revealing no striking differences in the NR1 subunit expression throughout the stratum oriens and the stratum pyramidale of the CA1 region, in the wild-type mice compared with the munc18-1 mutant mice. Insets, Higher magnification revealing a mainly somatic (asterisks) expression of the NR1 subunits in both groups. $C$, $D$, Immunostaining for the GluR2/3 subunit of the AMPA receptor on E17 hippocampal sections, showing similar GluR2/3 subunit expression throughout the strata oriens and pyramidale of the CA1 region, in the wild-type mice compared with the munc18-1 mutant mice. Insets, Higher magnification of double immunostaining for the GluR2/3 subunit of the AMPA receptor (green) and for MAP2 (red) showing in few pyramidal cells the presence of a short apical dendrite (arrows), decorated with GluR2/3 subunits. The asterisks indicate cell nuclei. $\boldsymbol{E}, \boldsymbol{F}$, Immunostaining for the $G A B A_{A}$ receptor on E17 hippocampal sections, illustrating the absence of any striking difference in the $G A B A_{A}$ subunit expression throughout the strata oriens, radiatum, and pyramidale of the CA1 region, in the wild-type mice compared with the munc18-1 mutant mice. Insets, Higher magnification showing a mainly somatic expression of the $\mathrm{GABA}_{A}$ receptors in both groups. The asterisks indicate cell nuclei, and arrows indicate apical dendrites. Scale bars: $20 \mu \mathrm{m}$; insets, $10 \mu \mathrm{m}$. s. or., Stratum oriens; s. pyr., stratum pyramidale; s. rad., stratum radiatum.

Using BrdU incorporation on isolated hippocampal organotypic slices, we found no significant difference in the total number of BrdU + migrated cells in wild-type slices $(118.67 \pm 31.69$ BrdU+ migrated cells; nine experiments) compared with munc18-1 slices $(146.33 \pm 13.65 \mathrm{BrdU}+$ migrated cells; $p=0.18$; three experiments). Furthermore, the amount of BrdU + mi- 
grated cells in the stratum pyramidale of the wild type (99.55 \pm 8.58 BrdU+ migrated cells in the stratum pyramidale; nine experiments) was not significantly different from the mutant $(70 \pm$ $25.16 \mathrm{BrdU}+$ migrated cells in the stratum pyramidale; $p=0.17$; three experiments). These observations suggest that neuronal migration is not affected by the absence of vesicular secretion of transmitters. Because transmitters are released by a SNAREindependent mechanism in these neurons (Demarque et al., 2002), we tested whether the effects of GABA and NMDA on neuronal migration persist in munc18-1-deficient mice.

\section{The effects of $\mathrm{GABA}_{\mathrm{A}}$ and NMDA receptor antagonists persist in hippocampal organotypic slices from munc18-1 mutant mice}

We investigated the effects of treatments with antagonists of the $\mathrm{GABA}_{\mathrm{A}}$ and the NMDA receptors on neuronal migration in the absence of transmitter secretion through synaptic vesicles in munc18-1 mutant mice. To quantify the effects of the application of receptor antagonists, we performed BrdU incorporation on isolated hippocampal organotypic slices from munc18-1 mutant mice (Fig. 6). On isolated slices as investigated here, we were able to study the impact of the absence of vesicular secretion of transmitters on migration, what could not have been possible on cocultivated slices, in which SNARE-dependent mechanisms could have been present in the GFP donor slice and in the GFP migrating cells. After 1 DIV in the presence of $10 \mu \mathrm{M}$ MK801, an antagonist of the NMDA receptors, the migration index was reduced by 7 units (from $10.01 \pm 3.45$ in the control condition to $2.86 \pm 1.54$ after MK801; eight experiments; 1385 cells) (Fig. $6 B$ ). However, this effect was not significant $(p=0.053)$ because of a relative variability of the data, and we could not exclude that part of the glutamate involved in the modulation of cell migration may have a vesicular origin. After $1 \mathrm{DIV}$ in the presence of $50 \mu \mathrm{M}$ bicuculline, an antagonist of the $\mathrm{GABA}_{\mathrm{A}}$ receptors, the migration index was reduced by 9 units (from $10.01 \pm 3.45$ in the control condition to $0.82 \pm 0.20$ after bicuculline; $p=0.002$; seven experiments; 1314 cells) (Fig. $6 \mathrm{~B}$ ). Thus, in the absence of vesicular release of transmitters through SNARE-dependent mechanisms, neuronal migration occurred but was impaired when cells were allowed to migrate in a medium supplemented with antagonists of receptors to the transmitters. This indicates that the activation of mainly $\mathrm{GABA}_{\mathrm{A}}$ receptors by endogenous transmitters still occurs in munc18-1-deficient mice and is involved in the modulation of CA1 pyramidal cell migration. This also suggests that transmitters (and mainly GABA) released independently of the SNARE machinery are able to modulate neuronal migration in a paracrine manner.

\section{Discussion}

Our results suggest that the release of GABA and glutamate through unconventional SNARE-independent mechanisms modulate neuronal migration. This is based on experiments showing that: (1) receptors to the transmitters GABA and glutamate are present in the migration area and are functional on migrating neuroblasts; (2) treatments with antagonists of the $\mathrm{GABA}_{\mathrm{A}}$ and the NMDA receptors strongly impair neuronal migration in our models; (3) neuronal migration and construction of the stratum pyramidale are normal in the absence of SNAREdependent vesicular secretion of transmitters in munc18-1 mutant mice; and (4) the effects of treatments with antagonists persist in munc18-1 mutant mice. Therefore, the early expression of receptors in neurons that bear no functional synapses enables a modulation of migration by endogenous GABA and glutamate,

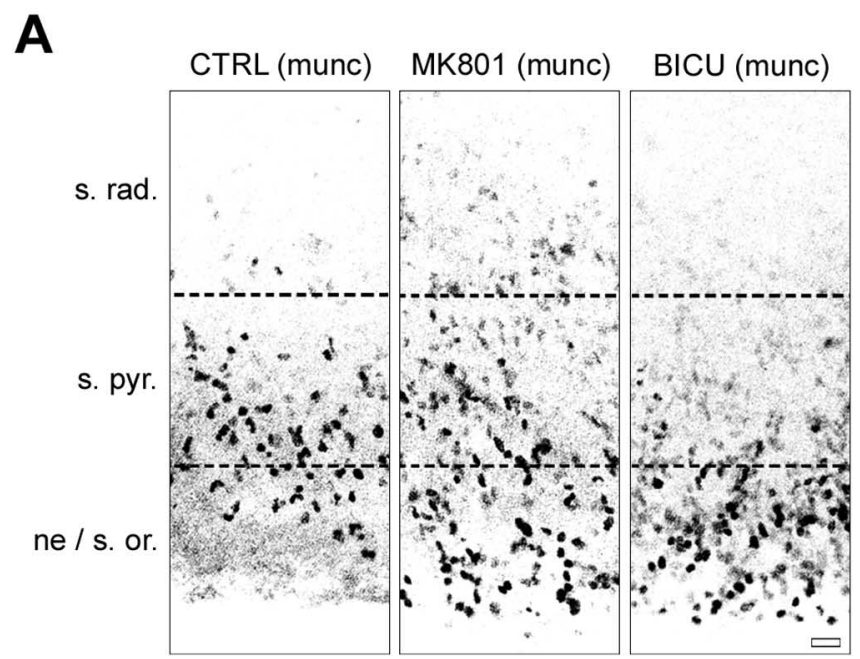

B

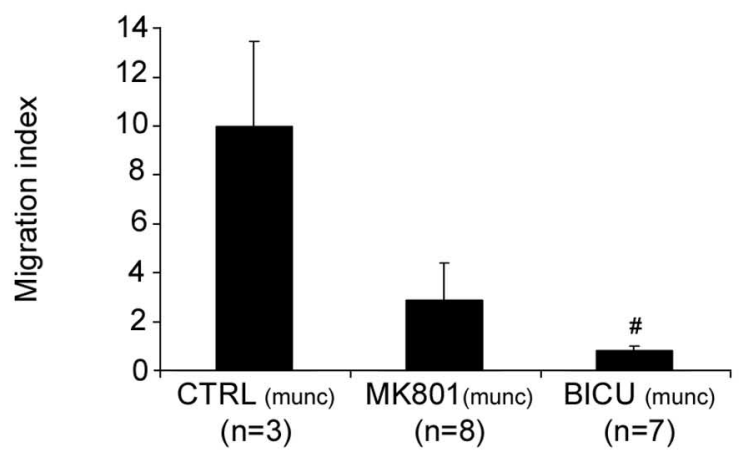

Figure 6. $\mathrm{GABA}_{\mathrm{A}}$ and NMDA receptor antagonists impaired the migration of BrdU-labeled cells in hippocampal organotypic slice culture from munc18-1 mutant mice. $A$, Immunostaining for BrdU on hippocampal organotypic slices from munc18-1 mutant mice cultured for 1 DIV without any treatment [control condition (munc); left ], in the presence of $10 \mu \mathrm{m}$ MK801 (middle), and in the presence of $50 \mu \mathrm{m}$ bicuculline (right). In the absence of any treatment in munc18-1 hippocampal slices, the BrdU + cells after 1 DIV are distributed partly into the migration area [i.e., neuroepithelium (ne)/stratum oriens (s. or.)] and partly into the stratum pyramidale (s. pyr.). After 1 DIV in the presence of MK801 and to a greater extent in the presence of bicuculline, BrdU + cells that have failed to migrate are distributed into the migration area. Scale bar, $20 \mu \mathrm{m}$. B, Histogram showing the migration indices obtained after treatment for 1 DIV with $10 \mu \mathrm{M}$ MK801 or $50 \mu \mathrm{m}$ bicuculline compared with the untreated control (munc) condition in hippocampal organotypic slice cultures from munc18-1 mutant mice. The migration indices are expressed ( \pm SEM) as the ratio between the percentage of cells that reached the stratum pyramidale after 1 DIV and the percentage of cells that were still in the migration area (i.e., from the neuroepithelium to the stratum oriens), with the average of the control values being set to $10{ }^{\#} p<0.01$. The number of experiments is given in parentheses. CTRL, Control; BICU, bicuculline.

possibly providing a mechanism for the activity-dependent regulation of brain development. Also, because these actions are not dependent on conventional vesicular release of transmitters, other mechanisms yet to be determined may control the presence and diffusion of transmitters in the extracellular space.

\section{Paracrine transmitters?}

Transmitters have been shown to play a crucial role in the modulation of brain construction, from the regulation of proliferation and migration to the modulation of differentiation and survival (Nguyen et al., 2001), acting in that sense as environmental (or epigenetic) factors. However, the mode of action of these transmitters and their mode of secretion are completely unknown. In our previous study (Demarque et al., 2002), we re- 
ported the presence of a paracrine mode of intercellular communication through transmitters in the developing hippocampus, at a stage in which synapses are absent. This paracrine communication is based on the activation of receptors present in cells that have no synapses, by endogenous transmitters released through calcium- and SNARE-independent mechanisms (Demarque et al., 2002). Here, we demonstrate that the transmitters involved in this paracrine nonsynaptic mode of communication may be responsible of the modulation of neuronal migration, thus confirming that paracrine transmitters influence brain construction. This study shed new light on the results of the numerous studies investigating the modulatory role played by the transmitters during CNS development (Komuro and Rakic, 1993; Behar et al., 1998, 1999, 2000, 2001; Fueshko et al., 1998; Hirai et al., 1999; Bless et al., 2000; Simonian and Herbison, 2001; Kihara et al., 2002; Lopez-Bendito et al., 2003). As suggested by Owens and Kriegstein (2002), one could hypothesize that the modulation of neuronal migration by transmitters in those previous studies might be mediated exclusively by a nonvesicular release.

These paracrine transmitters have a nonvesicular (or SNAREindependent) origin, but the exact origin and mode of secretion of these transmitters remains to be investigated. One could hypothesize that transmitters might be released either from more mature neurons in the vicinity of migrating neuroblasts and/or at the level of the target fields, or from glial cells (i.e., astrocytes or radial glial cells), or alternatively from migrating neuroblasts themselves [i.e., in an autocrine/paracrine manner (Bolteus and Bordey, 2004)]. The mode of secretion is also unknown, but we could suggest that transmitters might be released either through exchangers (Warr et al., 1999), gap junction hemichannels (Cotrina et al., 1998; Ye et al., 2003), ATP receptors (Wang et al., 2002; Duan et al., 2003), or volume-sensitive chloride channels (Kimelberg et al., 1990; Pasantes-Morales et al., 1994; Mongin and Kimelberg, 2002).

\section{Paracrine transmitters as developmental signals}

An increasing amount of evidences, including those provided in our study, suggest that transmitters act as developmental signals (Nguyen et al., 2001; Owens and Kriegstein, 2002). These "informative" transmitters may establish morphogenetic gradients that guide migrating neuroblasts to their target fields (i.e., positional signaling), or create a permissive substrate for migration, giving to the neuroblasts the conditions required for motility, or a combination of both. Transmitters may also establish and maintain a level of activity adequate for migrating neuroblasts to respond to the "classical" guidance cues. In addition, transmitters could stimulate the secretion of these guidance cues from surrounding cells, glial cells (astrocytes or radial glial cells) or more mature neurons, present along the migrating pathway and/or at the level of the target field. A "guiding action" of transmitters is unlikely because the leading process orientation (considered as an index of the direction of migration) is unaffected after treatments with antagonists in our study. However, we measured the leading process orientation of migrating neuroblasts "freezed" in the position they had just before fixation, bypassing the fact that the leading process is a highly dynamic structure. Additional studies, more dynamic (i.e., time-lapse high-power microscopy), are required and in process to answer that question. Interestingly, a study by Zheng et al. (1996) reported a turning response of the growth cones of Xenopus spinal neurons submitted to glutamate application, the turning response being blocked by the NMDA receptor antagonist AP-5. A "motility-promoting action" of transmitters is more likely, because the activation of the iono- tropic receptors by transmitters has been shown to evoke calcium influxes. This is the case for the activation of the NMDA receptors, coupled with a calcium conductance, as well as for the $\mathrm{GABA}_{\mathrm{A}}$ receptors, the activation of which in young postnatal hippocampal pyramidal cells and interneurons has been shown to induce intracellular calcium rise (Leinekugel et al., 1995). Furthermore, activation of $\mathrm{GABA}_{\mathrm{A}}$ and NMDA receptors in tangentially migrating interneurons has been shown to induce intracellular calcium rise (Soria and Valdeolmillos, 2002). The same group, however, showed recently that the intracellular calcium rise induced by pressure application of kainate, NMDA, or muscimol did not elicit motility (Moya and Valdeolmillos, 2004). These results are quite contradictory to the studies conducted by Komuro and Rakic (1998) and more recently by Kumada and Komuro (2004), which have demonstrated a tight correlation between calcium rise and motility in neurons migrating in the cerebellum, both being importantly decreased after blockade of NMDA receptors. Calcium orchestrated the dynamic of the cytoskeleton: the assembly of the microtubules (Rakic et al., 1996) as well as the assembly of the actin network (Rivas and Hatten, 1995). In that respect, the reduction in the length of the leading process observed after treatment with receptor antagonists in our study might be one of the consequences of a cystoskeleton disruption.

It would be interesting to investigate the response of migrating neuroblasts to transmitters as a function of their migratory status (i.e., resting cells vs actively migrating cells). We postulate that the morphologies of the migrating neuroblasts (orientation, length, and branching of their leading processes), as well as their responses to the transmitters would vary along their journey. Interestingly, we found a tonic activation of $\mathrm{GABA}_{\mathrm{A}}$ receptors in only $20 \%$ of assayed cells. Similar tonic $\mathrm{GABA}_{\mathrm{A}}$-generated currents have been observed in many cell types [including very immature CA1 pyramidal cells (Demarque et al., 2002)]. They might control neuronal excitability and information processing (Semyanov et al., 2004) and eventually contribute to modulate the motility of migrating neuroblasts.

To play a developmental role, paracrine transmitters should be able to diffuse into the extracellular space. This diffusion is allowed by the presence of a large, non-cohesive, extracellular space and a relative immaturity of the reuptake mechanisms, both creating the adequate conditions for a long-distance communication. Indeed, in the hippocampus, only glutamate transporters, but not the main GABA transporter GAT-1, contribute to the clearance of transmitters at birth (Demarque et al., 2002). This difference in the maturation of GABA transporters could explain the greater impact of the treatments with GABAergic antagonists in our study compared with glutamatergic antagonists. In addition, the difference in the functional expression of ionotropic receptors on migrating neuroblasts, as described in the present study, with the majority of cells expressing $\mathrm{GABA}_{\mathrm{A}}$ receptors argues in the same direction. This is in favor of a central role played by GABA as the key excitatory transmitter in developing brains (Represa and Ben-Ari, 2005). Other subtypes of GABA receptors such as $\mathrm{GABA}_{\mathrm{B}}$ might be involved in the modulation of migration in our model, as is the case for tangentially migrating interneurons (Lopez-Bendito et al., 2003). A role for $\mathrm{GABA}_{\mathrm{B}}$ receptors in the hippocampus is unlikely, because Gaiarsa et al. (1995) showed that postsynaptic $\mathrm{GABA}_{\mathrm{B}}$ receptors are absent or not functional during the first postnatal days in this structure.

In a more general perspective, it may be proposed that paracrine SNARE-independent transmitters contribute to modulate 
not only cell migration but also proliferation, neuronal maturation, and synaptogenesis. Thus, munc18-1 KO mice displayed a quite normal maturation of dendrites [MAP2 immunopositive (Demarque et al., 2002)] (Fig. 5), and ultrastructural analysis revealed that null mutants develop apparently normal synaptic structures (Verhage et al., 2000). However, spontaneous activity has been shown to result in calcium transients and to be critical for neurite outgrowth and pathfinding (Spitzer et al., 2000; Ciccolini et al., 2003; Tang et al., 2003). We therefore propose that paracrine SNARE-independent neurotransmitters contribute to this activity and modulate neuronal maturation.

In conclusion, together our data show that paracrine transmitters, glutamate and mainly GABA, act as crucial modulatory players of the brain construction. These paracrine transmitters are released independently of the conventional SNAREdependent mode of secretion and mediate their effects through the activation of $\mathrm{GABA}_{\mathrm{A}}$ and NMDA receptors. Because many pharmacological agents are likely to exert an influence on several neurotransmission systems during pregnancy, drug therapy during this period should be tightly controlled to avoid brain construction defects.

\section{References}

Anderson SA, Eisenstat DD, Shi L, Rubenstein JL (1997) Interneuron migration from basal forebrain to neocortex: dependence on Dlx genes. Science 278:474-476.

Bayer SA (1980) Development of the hippocampal region in the rat. I. Neurogenesis examined with $3 \mathrm{H}$-thymidine autoradiography. J Comp Neurol 190:87-114.

Behar TN, Schaffner AE, Scott CA, O'Connell C, Barker JL (1998) Differential response of cortical plate and ventricular zone cells to GABA as a migration stimulus. J Neurosci 18:6378-6387.

Behar TN, Scott CA, Greene CL, Wen X, Smith SV, Maric D, Liu QY, Colton CA, Barker JL (1999) Glutamate acting at NMDA receptors stimulates embryonic cortical neuronal migration. J Neurosci 19:4449-4461.

Behar TN, Schaffner AE, Scott CA, Greene CL, Barker JL (2000) GABA receptor antagonists modulate postmitotic cell migration in slice cultures of embryonic rat cortex. Cereb Cortex 10:899-909.

Behar TN, Smith SV, Kennedy RT, McKenzie JM, Maric I, Barker JL (2001) $\mathrm{GABA}_{\mathrm{B}}$ receptors mediate motility signals for migrating embryonic cortical cells. Cereb Cortex 11:744-753.

Bless EP, Westaway WA, Schwarting GA, Tobet SA (2000) Effects of gamma-aminobutyric acid(A) receptor manipulation on migrating gonadotropin-releasing hormone neurons through the entire migratory route in vivo and in vitro. Endocrinology 141:1254-1262.

Bolteus AJ, Bordey A (2004) GABA release and uptake regulate neuronal precursor migration in the postnatal subventricular zone. J Neurosci 24:7623-7631.

Ciccolini F, Collins TJ, Sudhoelter J, Lipp P, Berridge MJ, Bootman MD (2003) Local and global spontaneous calcium events regulate neurite outgrowth and onset of GABAergic phenotype during neural precursor differentiation. J Neurosci 23:103-111.

Cotrina ML, Lin JH, Alves-Rodrigues A, Liu S, Li J, Azmi-Ghadimi H, Kang J, Naus CC, Nedergaard M (1998) Connexins regulate calcium signaling by controlling ATP release. Proc Natl Acad Sci USA 95:15735-15740.

Demarque M, Represa A, Becq H, Khalilov I, Ben Ari Y, Aniksztejn L (2002) Paracrine intercellular communication by $\mathrm{a} \mathrm{Ca}^{2+}$ and SNAREindependent release of GABA and glutamate prior to synapse formation. Neuron 36:1051-1061.

Duan S, Anderson CM, Keung EC, Chen Y, Chen Y, Swanson RA (2003) $\mathrm{P} 2 \mathrm{X}_{7}$ receptor-mediated release of excitatory amino acids from astrocytes. J Neurosci 23:1320-1328.

Fueshko SM, Key S, Wray S (1998) GABA inhibits migration of luteinizing hormone-releasing hormone neurons in embryonic olfactory explants. J Neurosci 18:2560-2569.

Gaiarsa JL, Tseeb V, Ben Ari Y (1995) Postnatal development of pre- and postsynaptic GABAB-mediated inhibitions in the CA3 hippocampal region of the rat. J Neurophysiol 73:246-255.
Hata Y, Slaughter CA, Sudhof TC (1993) Synaptic vesicle fusion complex contains unc-18 homologue bound to syntaxin. Nature 366:347-351.

Hirai K, Yoshioka H, Kihara M, Hasegawa K, Sakamoto T, Sawada T, Fushiki S (1999) Inhibiting neuronal migration by blocking NMDA receptors in the embryonic rat cerebral cortex: a tissue culture study. Brain Res Dev Brain Res 114:63-67.

Kihara M, Yoshioka H, Hirai K, Hasegawa K, Kizaki Z, Sawada T (2002) Stimulation of $N$-methyl-D-aspartate (NMDA) receptors inhibits neuronal migration in embryonic cerebral cortex: a tissue culture study. Brain Res Dev Brain Res 138:195-198.

Kimelberg HK, Goderie SK, Higman S, Pang S, Waniewski RA (1990) Swelling-induced release of glutamate, aspartate, and taurine from astrocyte cultures. J Neurosci 10:1583-1591.

Komuro H, Rakic P (1993) Modulation of neuronal migration by NMDA receptors. Science 260:95-97.

Komuro H, Rakic P (1998) Orchestration of neuronal migration by activity of ion channels, neurotransmitter receptors, and intracellular $\mathrm{Ca}^{2+}$ fluctuations. J Neurobiol 37:110-130.

Kumada T, Komuro H (2004) Completion of neuronal migration regulated by loss of $\mathrm{Ca}^{2+}$ transients. Proc Natl Acad Sci USA 101:8479-8484.

Leinekugel X, Tseeb V, Ben Ari Y, Bregestovski P (1995) Synaptic GABAA activation induces $\mathrm{Ca}^{2+}$ rise in pyramidal cells and interneurons from rat neonatal hippocampal slices. J Physiol (Lond) 487:319-329.

Lopez-Bendito G, Lujan R, Shigemoto R, Ganter P, Paulsen O, Molnar Z (2003) Blockade of $\mathrm{GABA}_{\mathrm{B}}$ receptors alters the tangential migration of cortical neurons. Cereb Cortex 13:932-942.

Mongin AA, Kimelberg HK (2002) ATP potently modulates anion channelmediated excitatory amino acid release from cultured astrocytes. Am J Physiol Cell Physiol 283:C569-C578.

Moya F, Valdeolmillos M (2004) Polarized increase of calcium and nucleokinesis in tangentially migrating neurons. Cereb Cortex 14:610-618.

Nadarajah B, Parnavelas JG (2002) Modes of neuronal migration in the developing cerebral cortex. Nat Rev Neurosci 3:423-432.

Nguyen L, Rigo JM, Rocher V, Belachew S, Malgrange B, Rogister B, Leprince P, Moonen G (2001) Neurotransmitters as early signals for central nervous system development. Cell Tissue Res 305:187-202.

Okabe M, Ikawa M, Kominami K, Nakanishi T, Nishimune Y (1997) "Green mice" as a source of ubiquitous green cells. FEBS Lett 407:313-319.

O'Rourke NA, Dailey ME, Smith SJ, McConnell SK (1992) Diverse migratory pathways in the developing cerebral cortex. Science 258:299-302.

Owens DF, Kriegstein AR (2002) Developmental neurotransmitters? Neuron 36:989-991.

Pasantes-Morales H, Murray RA, Sanchez-Olea R, Moran J (1994) Regulatory volume decrease in cultured astrocytes. II. Permeability pathway to amino acids and polyols. Am J Physiol 266:C172-C178.

Paxinos G, Törk I, Tecott LH, Valentino KL (1991) Atlas of the developing rat brain. San Diego: Academic.

Rakic P (1971) Neuron-glia relationship during granule cell migration in developing cerebellar cortex. A Golgi and electronmicroscopic study in Macacus rhesus. J Comp Neurol 141:283-312.

Rakic P (1972) Mode of cell migration to the superficial layers of fetal monkey neocortex. J Comp Neurol 145:61-83.

Rakic P, Stensas LJ, Sayre E, Sidman RL (1974) Computer-aided threedimensional reconstruction and quantitative analysis of cells from serial electron microscopic montages of foetal monkey brain. Nature 250:31-34.

Rakic P, Knyihar-Csillik E, Csillik B (1996) Polarity of microtubule assemblies during neuronal cell migration. Proc Natl Acad Sci USA 93:9218-9222.

Represa A, Ben-Ari Y (2005) Trophic actions of GABA on neuronal development. Trends Neurosci, in press.

Rivas RJ, Hatten ME (1995) Motility and cytoskeletal organization of migrating cerebellar granule neurons. J Neurosci 15:981-989.

Rizo J, Sudhof TC (2002) Snares and Munc18 in synaptic vesicle fusion. Nat Rev Neurosci 3:641-653.

Semyanov A, Walker MC, Kullmann DM, Silver RA (2004) Tonically active $\mathrm{GABA}_{\mathrm{A}}$ receptors: modulating gain and maintaining the tone. Trends Neurosci 27:262-269.

Simonian SX, Herbison AE (2001) Differing, spatially restricted roles of ionotropic glutamate receptors in regulating the migration of $\mathrm{GnRH}$ neurons during embryogenesis. J Neurosci 21:934-943. 
Soria JM, Valdeolmillos M (2002) Receptor-activated calcium signals in tangentially migrating cortical cells. Cereb Cortex 12:831-839.

Spitzer NC, Lautermilch NJ, Smith RD, Gomez TM (2000) Coding of neuronal differentiation by calcium transients. BioEssays 22:811-817.

Stanfield BB, Cowan WM (1979) The development of the hippocampus and dentate gyrus in normal and reeler mice. J Comp Neurol 185:423-459.

Stoppini L, Buchs PA, Muller D (1991) A simple method for organotypic cultures of nervous tissue. J Neurosci Methods 37:173-182.

Tang F, Dent EW, Kalil K (2003) Spontaneous calcium transients in developing cortical neurons regulate axon outgrowth. J Neurosci 23:927-936.

Varoqueaux F, Sigler A, Rhee JS, Brose N, Enk C, Reim K, Rosenmund C (2002) Total arrest of spontaneous and evoked synaptic transmission but normal synaptogenesis in the absence of Munc13-mediated vesicle priming. Proc Natl Acad Sci USA 99:9037-9042.

Verhage M, Maia AS, Plomp JJ, Brussaard AB, Heeroma JH, Vermeer H,
Toonen RF, Hammer RE, van den Berg TK, Missler M, Geuze HJ, Sudhof TC (2000) Synaptic assembly of the brain in the absence of neurotransmitter secretion. Science 287:864-869.

Wang CM, Chang YY, Kuo JS, Sun SH (2002) Activation of P2X(7) receptors induced $\left[{ }^{3} \mathrm{H}\right] \mathrm{GABA}$ release from the RBA-2 type-2 astrocyte cell line through a $\mathrm{Cl}^{-} / \mathrm{HCO}^{3-}$-dependent mechanism. Glia 37:8-18.

Warr O, Takahashi M, Attwell D (1999) Modulation of extracellular glutamate concentration in rat brain slices by cystine-glutamate exchange. J Physiol (Lond) 514:783-793.

Ye ZC, Wyeth MS, Baltan-Tekkok S, Ransom BR (2003) Functional hemichannels in astrocytes: a novel mechanism of glutamate release. J Neurosci 23:3588-3596.

Zheng JQ, Wan JJ, Poo MM (1996) Essential role of filopodia in chemotropic turning of nerve growth cone induced by a glutamate gradient. J Neurosci 16:1140-1149. 